\title{
Modern Biotechnology, Agriculture, and Ethics
}

\author{
Per Sandin' ${ }^{1}$ Payam Moula ${ }^{2}$
}

Published online: 1 September 2015

(c) Springer Science+Business Media Dordrecht 2015

\section{Introduction}

Will crops developed using biotechnology save the world or trigger doomsday? From a quick glance at the debate on biotechnology and agriculture, one might get the impression that there are few possibilities in between-the debate has been characterized by a high degree of polarization (Van Haperen et al. 2012; cf. Gregorowius et al. 2012).

Those who believe in the potential of agricultural biotechnology usually refer to benefits in terms of increased yield, reduced environmental impact (Brookes and Barfoot 2008; Carpenter 2010; Mannion and Morse 2012), improved farmer health (Kouser and Qaim 2011) and higher economic impacts for adopting farmers in developing countries (Finger et al. 2011).

Critics of agricultural biotechnology question these benefits and raise concerns about potential risks, but they also tend to emphasize issues of social justice, for example because of dysfunctional institutions or regulatory regimes (Høyer Toft 2012), and other ethical considerations (Comstock 2000; Sandler 2004). In many parts of the world there has been vocal opposition to the use of biotechnology in agriculture in general, and in particular to the use of genetically modified (GM)

Selected papers from Mistra Workshop on Ethical Issues in New Biotechnology in Agriculture, Uppsala, Sweden, September 2013.

Per Sandin

per.sandin@slu.se

1 Department of Crop Production Ecology, Swedish University of Agricultural Sciences, P.O. Box 7043, SE-75007 Uppsala, Sweden

2 Department of Philosophy and History of Technology, Royal Institute of Technology, Brinellvägen 32, SE-100 44 Stockholm, Sweden 
crops for food. Focus has to a large extent been on biotechnology as a risk to human health and the environment (Bauer 2005), and it is not uncommon that this is combined with an argument to the effect that we know too little about the technology and that the unknowns might come back to haunt us (Smith 2007).

Still, the use of biotechnology in agriculture is increasing. Today, GM crops cover about $11 \%$ of the worlds cultivated area, around 180 million hectares compared to 1.7 million in 1996, with some crops being dominated by GM, for example $82 \%$ of the world's soybean, $68 \%$ of all cotton, $30 \%$ of all maize and $25 \%$ of canola (James 2014).

There are reasons to believe that the debate on biotechnologically altered crops in general, and GM ones in particular, might be entering a new phase.

First, new technologies make it unclear what is to count as a GM organism, both legally and ontologically. Within the EU regulatory regime, a number of new technologies have been under discussion during the last few years (Lusser et al. 2012), a discussion the outcome of which is yet unclear.

Secondly, the development of crop biotechnology is becoming less focused on agronomic traits than has been the case until now. Agronomic traits are intended to facilitate growing of the crop. Examples are GM crops that are resistant to pathogens or pests (such as Bt-toxin producing corn or ringspot-virus resistant papaya) or ones that are tolerant to herbicides such as glyphosate ('Roundup ready'). More recently, traits that provide the crops with environmentally beneficial characteristics or purported consumer benefits are increasingly developed and promoted. Two examples are:

- The 'golden bananas', beta-carotene enriched GM bananas undergoing human trials in Uganda. The work on the bananas was supported by the Bill and Melinda Gates Foundation (Walz 2014).

- The Innate Potato, a potato developed with the aid of genetic engineering for reduced browning and bruising, as well as lower levels of enzymes producing acrylamide (a potential carcinogen) and recently approved for commercial cultivation in the United States. Interestingly, the Innate Potato has been developed by a company which is not among the small number of large multinationals that are the major players in world of biotech crops (Walz 2015).

Several other products are in various stages of development.

Third, the idea of nature and naturalness are still important categories in the discussions about agriculture and ethics, with for instance the organic movement displaying a certain amount of ambivalence to biotechnology in agriculture (Ronald and Adamchak 2008). There has also been recent research on how to conceptualize naturalness and relate it to food and environment which might help bring the discussion forward (Siipi 2011, 2013). There have also been attempts made to approach naturalness in new dynamic ways specifically with regard to plant biotechnology (Van Haperen et al. 2012).

We believe that the time is ripe for a discussion of agricultural biotechnology that avoids polarization and that enables us to relate to these new developments. With a new array of technologies to alter crops the discussion needs to be cultivated and able to make distinctions and analyze differences between these new technologies. This 
was the background for the Mistra Biotech Workshop on Ethical Issues in New Biotechnology in Agriculture held in Uppsala, Sweden, on September 11, 2013, as a satellite event to the 11th Congress of the European Society for Agricultural and Food Ethics (EurSafe), and from which the papers in this special section emerge. The workshop contained invited and submitted papers, and we are pleased to be able to include contributions in the form of substantially expanded and revised versions of the workshop presentations by three contributors:

Lisa Heldke is Professor of Philosophy at Gustavus Adolphus College, St Peter, Minnesota. In her paper entitled 'Pragmatist philosophical reflections on GMOs', she examines the public debate about GMO technologies, as it is being carried out in its most dichotomizing forms in the United States. Her paper attempts to reveal the power of sharply dichotomous thinking, as well as its limits. She draws on the work of French philosopher Michel Serres, who uses the concept of the parasite to reconstruct or reframe fundamental dichotomies in western philosophy. It attempts a similar reframing of the public debates about GMOs. The purpose of such a reframing is to create possibilities for dialogue among participants that will move beyond the polarization that characterizes much of the current debate in the U.S.

Dane Scott is Director of the Mansfield Ethics and Public Affairs Program at The University of Montana and Associate Professor of Ethics in the College of Forestry and Conservation. In his contribution 'Freedom of cropping and the good life: Political philosophy and the conflict between the organic movement and the biotech industry over cross-contamination', he treats recent controversies over cross-contamination of crops in horticulture in the United States and the European Union. He describes how the root of these controversies is due to conflicts between the organic movement and the agricultural biotechnology industry and argues that the EU and US are both applying the moral and political philosophy of classical liberalism to resolve these conflicts by creating frameworks for coexistence between organic crops and GM crops. However, despite the EU and the US starting with the liberal principle of 'freedom of cropping' they have very different regulatory regimes for coexistence, which are respectively creating different sets of winners and losers. In the US the organic industry claims the system of coexistence is unfair and in the EU the biotech industry claims the system is unfair. Scott proposes that an alternative moral and political philosophy, communitarianism, better explains the deep conflict between the organic movement and the biotech industry and discusses the implications of using communitarianism as a moral framework for resolving the conflict over freedom of cropping, agriculture and the good life.

Helena Siipi is a Collegium Researcher at the Department of Behavioural Sciences and Philosophy, University of Turku, Finland. In her paper 'Is genetically modified food unnatural?' she notes that the term 'natural' and its antonym 'unnatural' are ambiguous and argues that GM food is unnatural in some senses of the term 'unnatural', but not in others. In particular, she argues that GM food is not necessarily unnatural in a sense that would offer a good reason for favoring food that is not GM.

In addition to all workshop contributors and participants, the editors wish to thank Anna Lehrman, Karin Edvardsson Björnberg and Helena Röcklinsberg for their contributions to the planning and execution of the workshop, and Mistra Biotech for financial support. Mistra Biotech is an interdisciplinary research 
programme focusing on the use of biotechnology for sustainable and competitive agriculture, funded by the Swedish Foundation for Strategic Environmental Research (Mistra) and the Swedish University of Agricultural Sciences (SLU).

\section{References}

Bauer, M. W. (2005). Distinguishing red and green biotechnology: Cultivation effects of the elite press. International Journal of Public Opinion Research, 17, 63-89.

Brookes, G., \& Barfoot, P. (2008). Global impact of biotech crops: Socio-economic and environmental effects, 1996-2006. AgBioForum, 11(1), 21-38.

Carpenter, J. E. (2010). Peer-reviewed surveys indicate positive impact of commercialized GM crops. Nature Biotechnology, 28(4), 319-321.

Comstock, G. (2000). Vexing nature? On the Ethical case against agricultural biotechnology. Dordrecht: Kluwer Academic Publishers.

Finger, R., El Benni, N., Kaphengst, T., et al. (2011). A meta analysis on farm-level costs and benefits of GM crops. Sustainability, 3(5), 743-762.

Gregorowius, D., Lindemann-Matthies, P., \& Huppenbauer, M. (2012). Ethical discourse on the use of genetically modified crops: A review of academic publications in the fields of ecology and environmental ethics. Journal of Agricultural and Environmental Ethics, 25, 265-293.

Høyer Toft, K. (2012). GMOs and global justice: Applying global justice theory to the case of genetically modified crops and foods. Journal of Agricultural and Environmental Ethics, 25, 223-237.

James, C. (2014). Global status of commercialized Biotech/GM crops: 2014. ISAAA brief no. 49. ISAAA: Ithaca, New York.

Kouser, S., \& Qaim, M. (2011). Impact of Bt cotton on pesticide poisoning in smallholder agriculture: A panel data analysis. Ecological Economics, 70, 2105-2113.

Lusser, M., Parisi, C., Plan, D., \& Rodríguez-Cerezo, E. (2012). Deployment of new biotechnologies in plant breeding. Nature Biotechnology, 30(3), 231-239.

Mannion, A. M., \& Morse, S. (2012). Biotechnology in agriculture: Agronomic and environmental considerations and reflections based on 15 years of GM crops. Progress in Physical Geography, 36, 747-763.

Ronald, P. C., \& Adamchak, R. W. (2008). Tomorrow's table: Organic farming, genetic, and the future of food. Oxford: Oxford University Press.

Sandler, R. (2004). An aretaic objection to agricultural biotechnology. Journal of Agricultural and Environmental Ethics, 17, 301-317.

Siipi, H. (2011). Non-backward-looking naturalness as an environmental value. Ethics, Policy and Environment, 14, 329-344.

Siipi, H. (2013). Is natural food healthy? Journal of Agricultural and Environmental Ethics, 26, 797-812.

Smith, J. M. (2007). Genetic roulette: The documented health risks of genetically engineered foods. Fairfield: Yes! Books.

Van Haperen, P. F., Gremmen, B., \& Jacobs, J. (2012). Reconstruction of the ethical debate on naturalness in discussions about plant-biotechnology. Journal of Agricultural and Environmental Ethics, 25, 797-812.

Walz, E. (2014). Vitamin A super banana in human trials. Nature Biotechnology, 32, 857.

Walz, E. (2015). USDA approves next-generation GM potato. Nature Biotechnology, 33, 12-13. 